\title{
Analysing ESP Learners' Needs at University of Muhammadiyah Malang for a Quality ESP Book
}

\author{
Alimin Adi Waloyo \\ Universitas Muhammadiyah Malang, Indonesia \\ email: aliminwaloyo@gmail.com
}

\begin{abstract}
English skills will automatically leave English for Specific Purposes (ESP) students (mechanical enginering, accounting, animal husbandry etc.) more opportunities to access international journals and textbooks related to their study. Therefore this research was conducted in order to analyze (1) learners/ target needs (necessities, lacks and wants) in ESP learning process in class. The learning outcomes were then used to determine ESP learning emphasized learners needs. So, the learning activities will be more fun and engaging. This study applied survey. The instrument to collect the data was questionnaire (likert scale) distributed to the 64 mechanical engineering students of University of Muhammadiyah Malang (UMM) as the subject. The data was analyzed using a simple statistical measurement for interpretation purposes. The research finding was divided into three. Firstly, the students necessities for ESP learning were to get connected globally through English and to prepare them for higher education. Secondly, their lacks of English competence are that they have less sufficient perfomance to complete the exercises in class. Lastly, regarding their wants, they expected that English would pave a road to gain a decent job in an international company.Therefore, ESP development has to focus on the students' preferences above as the priority. It means that ESP English teaching and textbooks ones are suggested to pay attention to those findings.

Keywords: Student needs, necessities, lacks and wants

\begin{tabular}{|c|c|c|}
\hline First Receive: & Revised: & Accepted: \\
2 Mei 2019 & 20 Mei 2019 & 3 Juni 2019 \\
\hline $\begin{array}{c}\text { Final Proof Recieved: } \\
\text { 10 Juni 2019 }\end{array}$ & Published: \\
\hline \multicolumn{3}{|c|}{ 21 Juni 2019 } \\
$\begin{array}{c}\text { Waloyo, A. A. (2019). Analysing ESP Learners' Needs at University of Muhammadiyah } \\
\text { Malang for a Quality ESP Book. Schemata, 8 (1), 51-60. }\end{array}$ \\
\hline \multicolumn{2}{|c|}{ How to cite (in APA style) } \\
\hline
\end{tabular}
\end{abstract}

\section{INTRODUCTION}

To enhance English language abilities, most departments at universities offer English for Specific Purposes (ESP) to their students. The ESP course is normally given to students in their first academic year.This course is provided for different study programs and, therefore, the materials are chosen accordingly based on their major. Therefore, they are expected to be able to recognize references to support their content courses learning and the students will be ready to work in international level companies due to their' English skills advancement. 
Alimin A. W., Analysing ESP Learners' Needs at University of Muhammadiyah Malang...

ESP is supposed to take the students preferences into accounts (Hutchinson \& Waters, 199193; Pamungkas \& Sukarno, 201694). Hutchinson, \& Waters (1991) added ESP textbooks and workbooks should consist of some important aspects such as learner/ target needs, aims of the material, content of the book, methodology used, and other criteria. ESP is directed to teach English for learners in order to shape specific expertise (Pamungkas \& Sukarno, 2016).Thus, ESP textbooks, used as a tool to teach English, are supposed to develop not only students linguistic proficiency but also prepare them to be ready to work in places requiring both English and their expertise.

There are some essential aspects of ESP teaching and textbooks. Those aspects are always going to be the main focus of ESP pedagogical activity and textbooks design. To simplify and ease the ESP materials development, including textbooks design,Hutchinson \& Waters (1987) proposed two elements that need to be taken into account: 1) target needs/ learners needs and 2) learning needs.

The target/ learners needs are classified into three:

a) Necessities: the demands of the target condition or function that ESP students need to know in order to communicate effectively in target situation, e.g. a mechanical engineering student needs to be able to explain the car engine issue to his customer. He presumably needs to recognize and understand the linguistic features, including technical vocabulary, discourse, function and structure applied in that situation.

b) Lacks: to identify what the learners have already known, so ESP teachers can determine in which language area the learners need to improve.

c) Wants: the ESP learners' actual encouragement or motivation in the English learning process which should not be ignored. So, taking into account the students' motivation in language learning process is crucial. Check figure 1 below, summarizing target needs concisely.

The learning needs, which was developed by Nunan (2004, p. 40), "consist of input, procedures, setting, teacher and student role". Regarding ESP textbooks, although both points are important for the design, learners/ target needs are crucially having more direct connection for an ESP book. While the classroom instruction requires both target needs and

\footnotetext{
${ }^{93}$ Hutchinson, T., \& Waters, A., English for specific purposes: A learning-centered approach. (Cambridge: Cambridge University Press,1991)

${ }^{94}$ Pamungkas, A. P., \& Sukarno, "Developing a set of supplementary learning materials of written cycle for students of grade XI of automotive engineering at vocational school,". English Lannguage Teaching 6. No.12 (2016): 1-6.
}

\section{Copyright $\odot 2019$ Schemata Journal}


Alimin A. W., Analysing ESP Learners' Needs at University of Muhammadiyah Malang...

learning needs because the activity directly involves students and teachers active engagement. Therefore, ESP textbooks or the suplementary ones need to heavily emphasized on learners needs investigation prior to their design.

Figure 1. ESP Textbook design schema

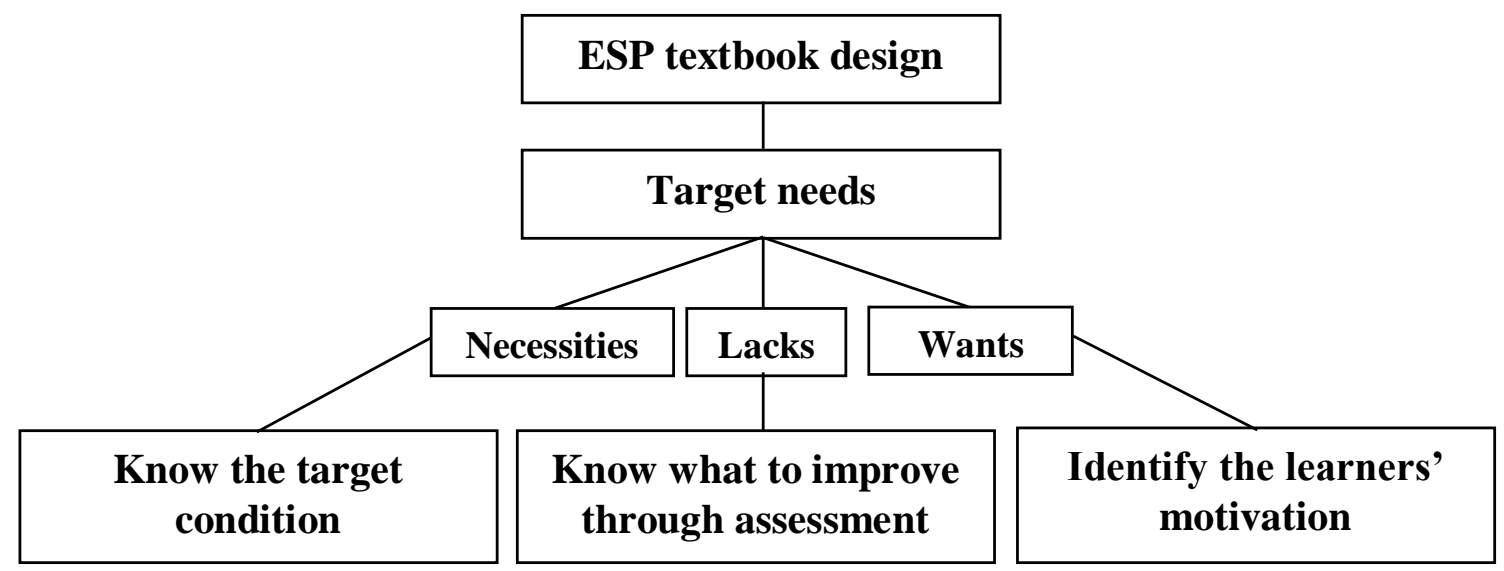

Tomlinson (1998, p.2) states that "materials are anything used by teachers and learners to achieve the learning goals". Good materials mean reliable ESP textbooks to refer to when the teachers teach English in class because ESP textbooks generally become the main reference to assist the teachers when teaching English in the classroom. Nevertheless, ESP textbooks sometimes create some difficulties for some students. For instance, many the textbooks contain topics which are not quite relevant to learners' background knowledge in certain field. Furthermore, the linguistics aspects discussed in class may not be in line with their prospective job. Thus, it is essential to conduct an in-depth needs assessment regarding the topics that will included in ESP textbooks. That way, learners will understand the material from the books easily.

Related to material development, particularly ESP textbooks, Nunan (1991, p.216) states that "material development is basically dealing with selection, adaptation and creation of teaching materials." In an ESP learning setting, it is clearly acceptable and understanable that the learners expect to achieve real world objectives, which requiring specific linguistic competencies (Basturkmen, 2010, p. 7).In other words, they believe their ESP classroom instruction would prepare them for not only language proficiency development but also required expertise to find a decent job.

Tomlison (2013) stated that materials evaluation is a procedure to determine whether the developed materials meet the practicality aspect of learning or not, and how the learners obtain the positive outcomes from them. "Materials evaluation is not a tool to determine

\section{Copyright () 2019 Schemata Journal}

Available online at http://journal.uinmataram.ac.id/index.php/schemata 
Alimin A. W., Analysing ESP Learners' Needs at University of Muhammadiyah Malang...

whether the learning materials are good or not, rather how its appropriatness in use" (Hutchinson and Waters, 1987, p. 96). Materials or textbooks evaluation can be in the form of methodical and well-structured research as done in the following studies.

Habbash (2014) investigation found students of engineering faculty at the University of Tabuk in Saudi Arabia had real needs and interest to develop English. These needs motivate them to study English and build their self-confidence in their English learning process. Furthermore, Evangeline \& Ganesh (2016) investigated a need analysis of technical writing skills of engineering students in India. The investigation found doing more reading tasks, presentations as well as assignments will help learners to enhance their technical writing skills.

Kamin, Ahmad, \& Cartledge, (2013) analyzed by comparing the needs of automotive industries and the educational teaching strategies to produce skilful workers between Malaysia and Australia. Using students, educators and employers as participants, the findings suggested to update the training facilities, relevance of applied curriculum towards technological rapid progess in the automotive industry. In addition, Pamungkas \& Sukarno (2016) investigated suplementary textbooks for automotive department at vocational school in Indonesia. They suggested the material development consider target/ learner needs (students did expect to pass the national examination and to be professional mechanics in famous automotive industries).

Based on the result of the relevant studies above, it can be concluded that some studies on need analysis for automotive engineering have been previously conducted in different countries including Indonesia. However, there is a missing point here. That is, the study conducted in Indonesia focused on a vocational school of automotive major. Thus, this study would like to expand the investigation to univeristy level, in which the subject is mechanical engineering students. What are learners/ target needs in ESP learning process in class? The purpose of this study was to investigate need analysis of mechanical engineering students which could be applied as a sound reference to design quality ESP textbooks

\section{RESEARCH METHOD}

This research applied quantitative method with simple number calculation. This research will involve 64 students. The students are second semester students of mechanical engineering at University of Muhammadiyah Malang acedemic year 2018/2019. These subjects are chosen because they experienced ESP learning and teaching directly in class.

\section{Copyright () 2019 Schemata Journal}

Available online at $\mathrm{http}: / /$ journal.uinmataram.ac.id/index.php/schemata 
Alimin A. W., Analysing ESP Learners' Needs at University of Mubammadiyah Malang...

Therefore, their answers will be relevant with the research situation and needs. As a result, they are reliable subject to in order to obtain the data.

This reserach implemented survey and the instruments to collect the data were questionnaire (in the form of likert scale between 1, representing strongly disagree and 5, representing strongly agree). The instruments was triangulated by professional ESP teachers and a pedagogic expert to ensure their validity and quality. See the simplified steps of data collection in figure 2 .

Figure 2 . Step by step of data collection

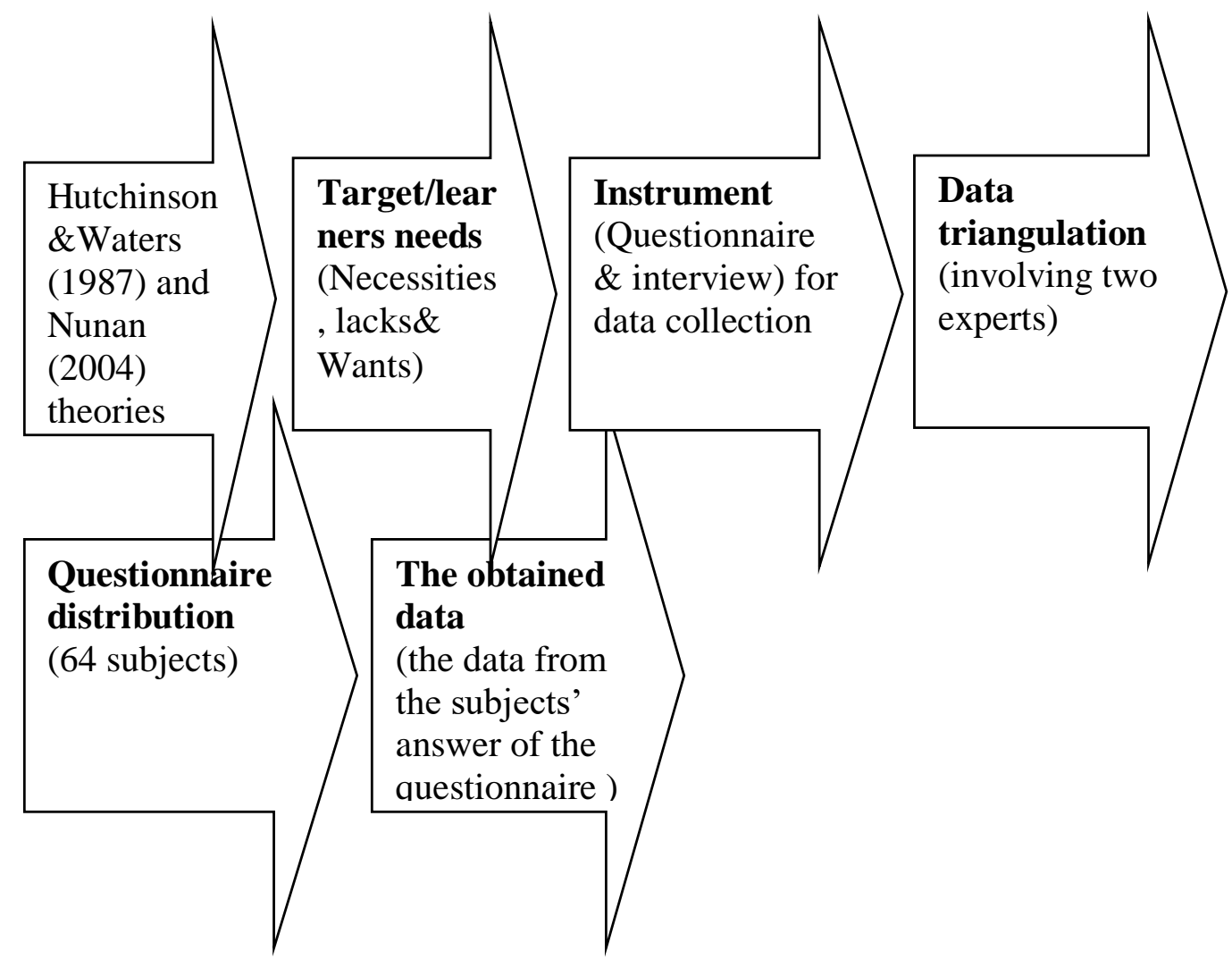


Alimin A. W., Analysing ESP Learners' Needs at University of Mubammadiyah Malang...

\section{FINDING AND DISCUSSION}

The research question of this investigation was to systematically identify the learners needs of ESP classroom learning process. The elaboration of the analysis result would be divided into three section: necessities (derived from questionnaire number 1-4), lacks (derived from questionnaire number 5-11), and wants (derived from questionnaire number 12-15). By applying simple statistical measurement to figure out the mean (M) of each statement in the questionnaire, the students' need (divided into necessities, lacks and wants) in ESL learning could be identified.

\section{a. Necessities in ESP learning}

To figure out the necessities in the context of learners needs when dealing with ESP classroom activities, the students answers extracted from question 1-4 of the questionnaire were statistically calculated.

From table 1 below, statement 1 clearly indicated that the learners believed learning English was crucial for better oral and written communication. From the second statement, they admitted that English is badly needed for supporting their future job, mechanical engineering departments or other related sectors as well as pursuing higher education, in which the mean score here is higher that the previous statement. Regarding statements number 3 and 4, students had agreed the importance of developing their English for linguistic as well as content purposes, but that agreement is lower than topics of learning English for broader international connections. Interestingly, learning English for broader international connection was ranked the highest as the necessity to learn English.

Table 1. Learners' necessities

ESP learners

$\begin{array}{ll}\text { Statement } & (\mathrm{N}=64)\end{array}$

$\mathrm{M}$

1. Learning English is important to help me communicate fluently 3.9 both orally and in written.

2. English is important to support my future job as a mechanical 4 engineer and/or pursue higher education.

3. English learning experience has to focus on both the linguistics 3.6 aspects (e.g., vocabulary, pronunciation, grammar, etc.) and content (e.g., coil, fuel injection, piston compression, gear ratio, wiring, dynamo etc).

4. Learning English is necessary to create broader international connections. 
Alimin A. W., Analysing ESP Learners' Needs at University of Muhammadiyah Malang...

Note: The M, representing mean, is statistically computated from the Likert scales ( $1=$ strongly disagree to $5=$ strongly agree) of the questionnaire question.

Related to necessities, learners' goal for learning English, particularly ESP are to stretch their connection to be more global. Another finding is the English or ESP lesson should be directed to prepar learners to be ready for working in the corporates or mechanical sectors requiring English and to make them ready for pursuing higher eduction. Therefore, the ESP textbook needs to provide more room for content-related topics than linguistics development focus. (Lestari, Syahrial, \& Suwarno, 2017) added that ESP courses need to emphasize job- or study-related needs, instead of common linguistics interests. Hence, ESP courses in class can fullfill learners need and expectation activating their motivation to learn English and lead English learning become more fun and enjoyable.

\section{b. Lacks in ESP learning}

Statements 5 up to 11 belong to lack that the learners face when developing their ESP. Therefore, those statements assessed the learners' lack related to their ESP. The following table 2 statistically highlighted how mechanical engineering students considered their English proficiency. They fairly had a neutral thoughts that writing and speaking activities with simple up to complex level are not difficult. However, the M scores, ,3.4 and 3.3, showed they just possessed fair confidence to be able to deal with any exercises related to those two skills, particularly statement 6 .

Moving to listening skills (statement 7 and 8), they agreed that listening to simple English statements or conversations is easier than the complex ones. Learners agreement in regard to answering English questions in a classroom setting is neutral (statement 9), but the lowest one compared to the other statements. This exhibited that English learning in class was a bit challenge for them.

When asked about their comprehension ability to deal with general English texts and content related references, the ESP students relatively had neutral view. Thus, both general and content-specific texts require them to think harder to understand the text meaning. Their strongest agreement on English proficiency went to listening to simple expressions and sentences (M: 3.5).

Table 2. Learners' lacks

\begin{tabular}{ll}
\hline \multirow{3}{*}{ Statement } & ESP learners \\
& $(\mathrm{N}=64)$ \\
\cline { 2 - 2 } & $\mathrm{M}$ \\
\hline
\end{tabular}


Alimin A. W., Analysing ESP Learners' Needs at University of Muhammadiyah Malang...

\footnotetext{
5. Writing and speaking with simple sentences and expressions 3.4 are easy.

6. Writing and speaking with complex sentences and 3.3 expressions are easy.

7. When listening to simple sentences and expression, I can 3.5 understand easily.

8. When listening to complex sentences and expression, I can 3.2 understand easily.

9. Answering questions from English materials in class is easy 3.0

10. I comprehend general English texts when reading them. $\quad 3.3$

11. I comprehend English references related to mechanical 3.1 engineering topics when reading them.

Note: The M, representing mean, is statistically computated from the Likert scales $(1=$ strongly disagree to $5=$ strongly agree) of the questionnaire question.
}

The study finding about the lack is that students hardest challenge in accordance with English instruction is completing English exercises in class. This situation can demotivate learners English learning and jeopardize their future career requiring English mastery. If the classroom tasks are connected to their subject-related topic, they may be able to do the tasks better although they are in English due to their background knowledge. As it is highlighted by (Basturkmen, 2010) that ESP courses [as well as tasks] need to be more specific in focus than general English ones because they emphasize on analysis of learners ${ }^{\text {ee }}$ needs.

\section{c. Wants in ESP learning}

What the students want when learning ESP is numerically displayed in Table 3. Learners' goal to study English due to comprehending English references was agreed. See statement 12 , which is closed to 4 . When mechanical engineering students were questioined about their preference whether or not they would like to focus more on content (e.g., car engine, coil, spark plug, fuel pump, etc.) than linguistics aspect, the students were in neutral position. Interestingly, the mean score for statement 13 is slightly higher, meaning the agree that learning English for content is more important.

Shifting to the last statement, number 15, it clearly indicated that students were so encouraged to develop their English because they had a higher expectation that having good English proficiency would lead them to work in an international company with high wage. Suprisingly, the M score is the highest among all statements in Table 3.

\section{Copyright $\odot 2019$ Schemata Journal}

Available online at http://journal.uinmataram.ac.id/index.php/schemata 
Alimin A. W., Analysing ESP Learners' Needs at University of Muhammadiyah Malang...

Table 3. Learners' wants

\begin{tabular}{ll}
\hline \multirow{3}{*}{ Statement } & ESP learners \\
\cline { 2 - 2 } & $\mathrm{N}=64)$ \\
\hline
\end{tabular}

12. I study English because I want to comprehend English references.

13. English materials should focus more on content than on linguistics aspects.

14. Linguistics aspects are more important than content in learning English.

15. I learn English because I want to work in an international company with high salary.

Note: The $\mathrm{M}$, representing mean, is statistically computated from the Likert scales $(1=$ strongly disagree to $5=$ strongly agree) of the questionnaire question.

The last subcategory (wants), the researcher analysis found mechanical engineering students expected to work in international companies with high salary and ESP learning need to pay more attention to mechanical-related topics over general English ones. In the context of the researcher who used to teach ESP and is currently editing the ESP book creation, he found ESP books are more linguistics centrist over content-related one. The methodical and structured shift into more content specific topic of ESP books need to be executed as quickly as possible. As highlighted by Basturkmen (2010: 7) that in an ESP teaching, "it is understood that the learner would want to achieve real world objectives, objectives requiring specific linguistic competencies."

To conclude, ESP books or suplementary books are supposed to be more aware of students' necessities (global connection and ready to work in mechanical sectors), lacks (too difficult ESP classroom exercises) and wants (more content-related topics for working in international cooperates). In a result, students will be more excited and motivated to attending ESP class and they could be actively involved in classroom discussion and completing the exercises. At the end of the day, they are having sufficient English competent particularly in their fields which get learners expand their connection globally and ready to work in mechanical sectors necessitating English there.

\section{CONCLUSION}

Nunan (2004) highlighted language is supposed to be thought as a means to ease communication rather than as lists of lexical, phonological and grammatical items for 
Alimin A. W., Analysing ESP Learners' Needs at University of Muhammadiyah Malang...

memorization. Based on the investigation, ESP advancement for mechanical engineering students need to take into account the three aspects, necessities, lacks and wants. Firstly, the necessities for ESP learning are for global communication working in related sectors and ready for higher education. Next, learners have lacks in completing English tasks in class. Linguistics emphasized exercises could be one of the main reasons of that. Lastly, Regarding the wants, students expected English lead them to work in an international company and more content-related focus.

To optimize ESP learning opportunities and outcomes, classroom activities and ESP book creation are supposed to refer to the findings above. (Hutchinson \& Waters, 1987; Pamungkas \& Sukarno, 2016) strengthened that ESP development needs to emphasize the students' preferences as the priority.

Related to the researcher case, this study outcomes would be very useful as his plan to design an ESP textbook for mecahinal engineering students. By taking into account the students' necessities, lacks and wants above, the book is expected to fulfill mechanical engineering students expectation resulting better learning outcomes.

\section{REFERENCES}

Basturkmen, H. (2010). Developing courses in English for specific purposes. Auckland. New Zealand: University of Auckland.

Evangeline, J. C. K., \& Ganesh, K. (2016). A need analysis of technical writing skill of engineering students in India, 1090.

Habbash, M. M. (2014). Need analysis of engineering students' English needs at the University of Tabuk. Journal of Education and Practice, 5(38).

Hutchinson, T., \& Waters, A. (1991). English for specific purposes: A learning-centered approach. Cambridge: Cambridge University Press.

Kamin, Y., Ahmad, A., \& Cartledge, D. (2013). Students 'perceptions on the relevance of a diploma in an automotive curriculum to the workplace. Procedia - Social and Behavioral Sciences, 93, 90-96. https://doi.org/10.1016/j.sbspro.2013.09.157

Lestari, S., Syahrial, \& Suwarno, B. (2017). Language skills, sub-skills and vocabularies needed by automotive department students of technical high school: A need analysis study. Journal of Applied Linguistics and Literature, 2(2), 65-75.

Nunan, D. (1991). Language teaching methodology: A textbook for teachers. London: Prentice Hall International.

Pamungkas, A. P., \& Sukarno. (2016). Developing a set of supplementary learning materials of written cycle for students of grade XI of automotive engineering at vocational school. English Lannguage Teaching, 6(12), 1-6.

Tomlinson, B. (1998). Materials development in language teaching. Cambridge: Cambridge University Press.

\section{Copyright $\odot 2019$ Schemata Journal}

Available online at http://journal.uinmataram.ac.id/index.php/schemata 